\title{
Managing Injected Water Composition To Improve Oil Recovery: A Case Study of North
} Sea Chalk Reservoirs

\author{
Zahid, Adeel; Shapiro, Alexander; Stenby, Erling Halfdan; Yan, Wei
}

\section{Published in:}

Energy \& Fuels

Link to article, DOI:

$10.1021 /$ ef2008979

Publication date:

2012

Document Version

Publisher's PDF, also known as Version of record

Link back to DTU Orbit

Citation (APA):

Zahid, A., Shapiro, A., Stenby, E. H., \& Yan, W. (2012). Managing Injected Water Composition To Improve Oil Recovery: A Case Study of North Sea Chalk Reservoirs. Energy \& Fuels, 26(6), 3407-3415.

https://doi.org/10.1021/ef2008979

\section{General rights}

Copyright and moral rights for the publications made accessible in the public portal are retained by the authors and/or other copyright owners and it is a condition of accessing publications that users recognise and abide by the legal requirements associated with these rights.

- Users may download and print one copy of any publication from the public portal for the purpose of private study or research.

- You may not further distribute the material or use it for any profit-making activity or commercial gain

- You may freely distribute the URL identifying the publication in the public portal 


\title{
Managing Injected Water Composition To Improve Oil Recovery: A Case Study of North Sea Chalk Reservoirs
}

\author{
Adeel Zahid, ${ }^{\dagger}$ Alexander Shapiro, ${ }^{\dagger}{ }^{\dagger}$ Erling H. Stenby, ${ }^{\ddagger}$ and Wei Yan ${ }^{\dagger}$ \\ ${ }^{\dagger}$ Department of Chemical and Biochemical Engineering, and Department of Chemistry, Technical University of Denmark, DK-2800 \\ Lyngby, Denmark
}

\begin{abstract}
In recent years, many core displacement experiments of oil by seawater performed on chalk rock samples have reported $\mathrm{SO}_{4}{ }^{2-}, \mathrm{Ca}^{2+}$, and $\mathrm{Mg}^{2+}$ as potential determining ions for improving oil recovery. Most of these studies were carried out with outcrop chalk core plugs. The objective of this study is to investigate the potential of the advanced waterflooding process by carrying out experiments with reservoir chalk samples. The study results in a better understanding of the mechanisms involved in increasing the oil recovery with potential determining ions. We carried out waterflooding instead of spontaneous imbibition, which has been applied in most of the previous studies. Two different flooding schemes (with and without aging) were used for flooding North Sea reservoir chalk samples. For comparison, two tests were also carried out with Stevns Klint core plugs. The flooding tests were carried out with the following injecting fluids: distilled water, brine with and without sulfate, and brine containing only magnesium ions. The total oil recovery, recovery rate, and interaction mechanisms of ions with rock were studied for different injecting fluids at different temperatures and wettability conditions. Studies of the temperature dependence of the oil recovery indicated that the interaction of the ions contained in brine with the rock cannot be the only determining mechanism of enhanced recovery. We observed no substitution of $\mathrm{Ca}^{2+}$ ions with $\mathrm{Mg}^{2+}$ ions at high temperatures for both rocks. Not only the injection brine composition but also the formation water composition affected the oil recovery at high temperatures from the Stevns Klint chalk rock.
\end{abstract}

\section{INTRODUCTION}

Waterflooding has been the most widely used oil recovery method for many decades. Historically, the injected brine salinity was not considered as an important factor influencing the amount of oil recovered. However, over the past decade many studies have shown that waterflooding can be significantly improved by manipulating the injected brine chemistry for both sandstone and carbonate reservoirs. ${ }^{1-5}$ The exceptional success of seawater injection in the Ekofisk chalk reservoir $^{6}$ has been the motivation for a number of experimental studies to understand complex crude oil/water/ rock chemical interactions for carbonate reservoirs.

Several laboratory experimental studies of water injection were carried out by Austad and co-workers, who used different core plugs and studied recovery as a function of brine composition and temperature. ${ }^{5,7-10}$ It was observed that $\mathrm{SO}_{4}{ }^{2-}, \mathrm{Ca}^{2+}$, and $\mathrm{Mg}^{2+}$ are the potential determining ions for improving the oil recovery in chalk reservoirs at high temperatures (above $90{ }^{\circ} \mathrm{C}$ ). It was also reported that these ions must act together, because none of them alone had an effect on spontaneous imbibition. On the basis of these experimental results, wettability alteration was proposed to be a key reason for the improvement of oil recovery. A schematic model of the chemical mechanism for wettability modification was suggested. According to this model, the ions adsorb to the rock surface, which changes the surface charge, so that the adsorbed crude oil may be removed from the rock.

Webb et al. ${ }^{11}$ presented a comparative study of the oil recovery from a North Sea carbonate core sample with simulated $\mathrm{SO}_{4}{ }^{2-}$-free brine and seawater containing $\mathrm{SO}_{4}{ }^{2-}$ under reservoir conditions. The imbibition tests were performed with live oil. It was concluded that the wettability alteration of the carbonate rock with the $\mathrm{SO}_{4}{ }^{2-}$ ion is responsible for the saturation changes.

Fjelde et al. ${ }^{12}$ carried out spontaneous imbibition experiments using seawater and formation brine with core plugs from two fractured chalk fields at reservoir temperature. Only a small increase in oil recovery was observed with the seawater compared to the formation brine (containing no $\mathrm{SO}_{4}{ }^{2-}$ ) for reservoir core plugs compared to Stevns Klint outcrop chalk core plugs. Karoussi et al. ${ }^{13}$ investigated extreme cases of waterflooding of Stevns Klint core plugs with ion-free water and water containing just $\mathrm{Mg}^{2+}$ or $\mathrm{SO}_{4}{ }^{2-}$ ions. Water saturated with $\mathrm{Mg}^{2+}$ ions alone showed the highest oil recovery in the spontaneous imbibition experiments. Madland et al. ${ }^{14}$ studied the effect of aqueous chemistry on the mechanical strength of chalk. Hydrostatic creep tests were carried out with continuous flooding of seawater, distilled water, $\mathrm{NaCl}$, and $\mathrm{MgCl}_{2}$. It was shown that the presence of only $\mathrm{Mg}^{2+}$ in the injected brine can deform the rock. Bagci et al. ${ }^{15}$ also studied the effect of brine composition on oil recovery by waterflooding. Experiments were carried out with different brine compositions $(\mathrm{NaCl}, \mathrm{KCl}$, $\mathrm{CaCl}_{2}$, and mixed brines, such as 2 wt $\% \mathrm{KCl}+2$ wt $\% \mathrm{NaCl}, 2$ wt $\% \mathrm{KCl}+5$ wt $\% \mathrm{CaCl}_{2}$, etc.). The highest oil recovery (18.8\% higher than under distilled water injection) was observed for the $2 \mathrm{wt} \% \mathrm{KCl}$ brine. No analysis of the reasons for such a recovery variation was presented.

Received: June 20, 2011

Revised: $\quad$ May 9, 2012

Published: May 11, 2012 
In most of the studies discussed above, outcrop chalk core plugs were used. Very few studies have been carried out using reservoir chalk core plugs. To our knowledge, no single study has yet been reported in the literature about the interaction of potential determining ions with the reservoir rock at different temperatures and under different wetting conditions with regard to oil recovery.

The objectives of this study are (1) to experimentally investigate the oil recovery potential of the advanced waterflooding process for reservoir chalk samples at different wettability and temperature conditions, (2) to investigate reactivity of the potential determining ions toward the reservoir chalk surface, and (3) to compare the reservoir chalk and the Stevns Klint outcrop core plugs with respect to oil recovery and reactivity of the potential determining ions under the same experimental conditions.

The flooding tests with North Sea chalk samples were carried out both with and without aging at different temperatures and using different injected brine solutions. For comparison, similar experiments were performed with the Stevns Klint outcrop chalk cores. All of the flooding experiments were designed so that we could study both the oil recovery and the affinity of the potential determining ions with the chalk surface.

We carried out waterflooding instead of spontaneous imbibition, which was applied in most of the previous studies. Skauge et al. ${ }^{16}$ reported high oil recovery for a carbonate core sample that showed no spontaneous water imbibition. The study of the forced injection is important, because viscous and gravity forces usually prevail over capillary forces at characteristic reservoir scales.

The paper is structured in the following way: The experimental methodology is described in the next section. The subsequent sections provide the results of the laboratory core flooding study and detailed discussion. Finally, the conclusions are drawn.

\section{EXPERIMENTAL SECTION}

2.1. Core Plugs. Outcrop Stevns Klint core plugs and core plugs from two different North Sea chalk reservoirs were used in the experiments.

The outcrop chalk is of Maastrichtian age and has a large specific surface area of around $2 \mathrm{~m}^{2} / \mathrm{g}$, as determined by nitrogen adsorption. ${ }^{17}$ The porosity is about $46-48 \%$, and the permeability is about $6-7 \mathrm{mD}$. The core plugs are very homogeneous with regard to permeability and porosity, which makes them suitable for parametric studies. The Stevns Klint core plugs were $3.6-3.8 \mathrm{~cm}$ in diameter and $7-8 \mathrm{~cm}$ in length. The core plugs were provided by the Danish Geotechnical Institute (GEO).

The core plugs from two different North Sea chalk reservoirs (1L and RE05) have a specific surface area of 2.06 and $2.10 \mathrm{~m}^{2} / \mathrm{g}$, respectively, as determined by Brunauer-Emmett-Teller (BET). The detailed properties of all of the core plugs used in this study are given in Table 1. To confirm the homogeneity of the cores and absence of fissures, X-ray computer tomography (CT) scan analysis was performed on each core plug.

2.2. Crude Oil. We used North Sea dead crude oil for this study. No model oil was used, because the goal was to provide more realistic fluid-fluid and fluid-rock interactions. Puntervold et al. ${ }^{18}$ observed that natural and model oils behave differently during displacement. Our studies ${ }^{19}$ also indicated that the results of the recovery by waterflooding are strongly oil-dependent.

Acid and base numbers of the crude oil were measured using Metrohm 702 SM Titrino by the methods developed by Fan and Buckley $^{20}$ [modified versions of American Society for Testing and Materials (ASTM) D2896 for the base number titration and ASTM
Table 1. Core Plug Properties

\begin{tabular}{lcccc}
$\quad$ name of plug & $\begin{array}{c}\text { length } \\
(\mathrm{cm})\end{array}$ & $\begin{array}{c}\text { diameter } \\
(\mathrm{cm})\end{array}$ & $\begin{array}{c}\text { porosity } \\
(\%)\end{array}$ & $\begin{array}{c}\text { permeability } \\
(\mathrm{mD})\end{array}$ \\
$\begin{array}{l}\text { North Sea (1L) } \\
\text { North Sea }\end{array}$ & 5.79 & 2.57 & 31.74 & 0.97 \\
$\quad$ (RE05) & 7.47 & 3.72 & 37.87 & 0.83 \\
Stevns Klint-1 & 7.70 & 3.69 & $47-50$ & 6.48 \\
Stevns Klint-2 & 7.86 & 3.82 & $47-50$ & 6.96 \\
\hline
\end{tabular}

D664 for the acid number titration]. Density, acid number, base number, and viscosity of the crude oil are given in Table 2 .

Table 2. Crude Oil Properties

\begin{tabular}{lcrr} 
& SWOS (ppm) & SW3S (ppm) & FW (ppm) \\
$\mathrm{Na}^{+}$ & 8471.18 & 7758.46 & 31022.62 \\
$\mathrm{~K}^{+}$ & 390.98 & 390.98 & 521.84 \\
$\mathrm{Mg}^{2+}$ & 1093.73 & 1093.73 & 664.95 \\
$\mathrm{Ca}^{2+}$ & 521.01 & 521.01 & 5667.24 \\
$\mathrm{Cl}^{-}$ & 17459.61 & 11255.33 & 60272.08 \\
$\mathrm{HCO}_{3}{ }^{-}$ & 122.03 & 122.03 & 13.07 \\
$\mathrm{SO}_{4}{ }^{2-}$ & 0.000 & 6916.32 & 0.000 \\
$\mathrm{TDS}(\mathrm{g} / \mathrm{L})$ & 33.39 & 33.39 & 98.158 \\
\hline
\end{tabular}

2.3. Brine Solutions. The synthetic brine solutions were prepared by adding different amounts of $\mathrm{NaCl}, \mathrm{NaHCO}_{3}, \mathrm{KCl}, \mathrm{MgCl}_{2} \cdot 6 \mathrm{H}_{2} \mathrm{O}$, $\mathrm{CaCl}_{2} \cdot 2 \mathrm{H}_{2} \mathrm{O}$, and $\mathrm{Na}_{2} \mathrm{SO}_{4}$ to distilled water. Three different brine solutions were prepared for injection: (1) synthetic seawater without sulfate ions (SWOS), (2) sulfate concentration 3 times larger than in the synthetic seawater (SW3S), and (3) $0.1 \mathrm{M} \mathrm{MgCl}_{2}(0.1 \mathrm{M} \mathrm{Mg}$ ). The total dissolved solid for the first two brine solutions was made similar by adjusting the amount of $\mathrm{NaCl}$. North Sea synthetic formation water (FW) was also prepared for use as initial water in the tests. The detailed compositions of all of the brine solutions are given in Table 3.

2.4. Core Preparation. Prior to any flooding experiment, the core plugs from the North Sea reservoirs were cleaned. They were put into a Hassler core holder, flooded with toluene until the effluent was colorless, and then flooded with ethanol. After cleaning, the core plugs were dried in an oven at $90{ }^{\circ} \mathrm{C}$ to a constant weight and then evacuated. The dried core plugs were flooded with distilled water at 40 ${ }^{\circ} \mathrm{C}$. The pore volume was calculated by comparing the weights of the dry and saturated cores. We established initial water saturation (IWS) by flooding the confined core by 5-7 pore volumes (pv) of crude oil at an injection rate of $0.2 \mathrm{~cm}^{3} / \mathrm{min}$ at $70{ }^{\circ} \mathrm{C}$. Afterward, the two different flooding sequences were applied, as shown in Figure 1. Flooding sequence 1 was without aging of the plug in crude oil, while flooding sequence 2 involved aging. For aging in flooding sequence 2, three pore volumes of crude oil were flooded from both sides of the core plug. The saturated core was then aged for 3 days at $80{ }^{\circ} \mathrm{C}$. Flooding sequence 2 was not applied to the second North Sea chalk sample RE05. We assumed that solvent-cleaned reservoir cores are water-wet and remain so during flooding sequence 1 and that it changes to more oil-wet during sequence 2 .

The drilled core plugs from Stevns Klint were dried in the oven at $90{ }^{\circ} \mathrm{C}$ overnight. Then, they were saturated with a brine solution for 3 $\mathrm{h}$ under vacuum, after which the pore volume was calculated for each core plug. The IWS was established in the same way as for the reservoir core plug. No aging was carried out with the Stevns Klint plugs.

IWS is high in the core plugs compared to average saturation in reservoirs. Tang et al. ${ }^{21}$ conducted a study on the effect of IWS on oil recovery with Kansas outcrop chalk samples (Kansas outcrop chalk is very similar to the rock matrix of the North Sea fractured chalk reservoirs). They concluded that the effect of IWS on oil recovery depends upon wettability. IWS has a significant effect on water injection in an intermediate-wet chalk. This effect is much less 
Table 3. Different Brine Compositions

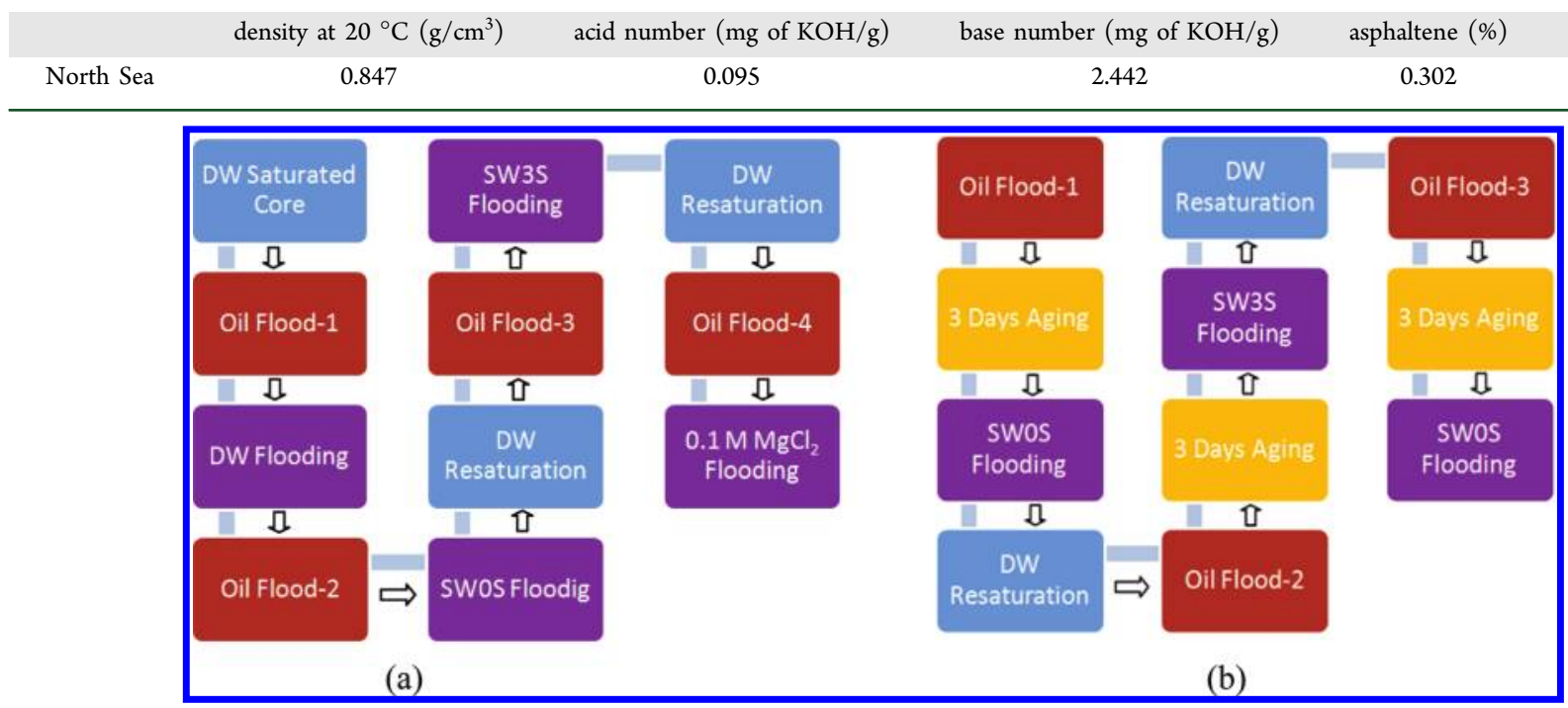

Figure 1. (a) Flooding sequence 1 without aging and (b) flooding sequence 2 with aging: DW, distilled water; SWOS, synthetic seawater without sulfate ions; and SW3S, sulfate concentration 3 times larger than in the synthetic seawater.

pronounced for a water-wet chalk. In our study, flooding sequence 1 with reservoir chalks and tests with Stevns Klint are at water-wetting conditions (without aging). Therefore, in these cases, possibly the effect is less pronounced. It could affect the two tests in flooding sequence 2 with reservoir chalk core plug (1L).

2.5. Flooding Schemes. In all of the experiments, flooding was initially carried out at $40{ }^{\circ} \mathrm{C}$. When no more oil came out, the temperature was increased to $70{ }^{\circ} \mathrm{C}$ and finally to $120{ }^{\circ} \mathrm{C}$. The flooding tests were carried out with a sleeve pressure of 70 bar for the reservoir core plugs and 30 bar for the outcrop core plugs. A back pressure of 12 bar was used for all of the experiments to avoid boiling of the liquids. The volume of produced oil was measured as a function of pore volumes injected. All flooding tests are listed in Table 4.

\section{Table 4. Summary of Flooding Tests}

\begin{tabular}{|c|c|c|c|c|c|}
\hline core plugs & $\begin{array}{c}\text { cycle } \\
\text { number }\end{array}$ & $\begin{array}{l}\text { injected } \\
\text { fluid }\end{array}$ & $\begin{array}{l}\text { initial } \\
\text { water }\end{array}$ & $\begin{array}{l}\text { IWS } \\
(\%)\end{array}$ & $\begin{array}{c}\text { oil recovery } \\
(\% \text { OOIP) }\end{array}$ \\
\hline \multicolumn{6}{|c|}{ Flooding Sequence 1, without Aging } \\
\hline \multirow{4}{*}{$\begin{array}{l}\text { North Sea } \\
(1 \mathrm{~L})\end{array}$} & 1 & DW & DW & 32.3 & 53.1 \\
\hline & 2 & SWOS & DW & 34.4 & 54.4 \\
\hline & 3 & SW3S & DW & 33.4 & 56.1 \\
\hline & 4 & $0.1 \mathrm{MgCl}_{2}$ & DW & 32.3 & 53.8 \\
\hline \multicolumn{6}{|c|}{ Flooding Sequence 2, with Aging } \\
\hline \multirow{4}{*}{$\begin{array}{l}\text { North Sea } \\
\quad(1 \mathrm{~L})\end{array}$} & 1 & SW0S & DW & 34.4 & 50.7 \\
\hline & 2 & SW3S & DW & 36.4 & 53.4 \\
\hline & 3 & SWOS & DW & 35.1 & 50.9 \\
\hline & \multicolumn{4}{|c|}{ Flooding Sequence 1, without Aging } & \\
\hline $\begin{array}{l}\text { North Sea } \\
\text { (1L) }\end{array}$ & 1 & SW3S & FW & 27.4 & 58.4 \\
\hline \multirow{2}{*}{$\begin{array}{l}\text { North Sea } \\
\text { (RE05) }\end{array}$} & 1 & SWOS & DW & 13.1 & 53.1 \\
\hline & 2 & SW3S & DW & 14.2 & 54.2 \\
\hline Stevns Klint-1 & 1 & SW3S & DW & 31.2 & 37.9 \\
\hline Stevns Klint-2 & 1 & SW3S & FW & 20.2 & 43.5 \\
\hline
\end{tabular}

2.6. Chemical Analysis. Effluent was collected by means of a fractional collector at different time intervals and analyzed for potential determining ions $\left(\mathrm{SO}_{4}{ }^{2-}, \mathrm{Ca}^{2+}\right.$, and $\left.\mathrm{Mg}^{2+}\right)$. The $\mathrm{SO}_{4}{ }^{2-}$ ion was detected with the ion chromatograph DX-120 produced by Dionex, Sunnyvale, CA. The $\mathrm{Ca}^{2+}$ and $\mathrm{Mg}^{2+}$ ions were analyzed with the inductive coupled plasma (ICP) Varian 720-ES. The effluent samples were diluted with deionized water before the analysis to meet the concentration limits of the equipment.

\section{RESULTS}

3.1. North Sea Chalk Reservoir Core Plug (1L). 3.1.1. Flooding Sequence 1. In flooding sequence 1 , a preliminary flooding test was carried out at $40{ }^{\circ} \mathrm{C}$ with a plug initially saturated by oil and distilled water. First, distilled water was injected at a relatively slow injection rate of $2 \mathrm{pv} /$ day. When the production stopped, the temperature of the system was increased to $70{ }^{\circ} \mathrm{C}$ and finally to $120{ }^{\circ} \mathrm{C}$. As shown in Figure 2, 53.1\% original oil in place (OOIP) was recovered after injection of the distilled water at $40{ }^{\circ} \mathrm{C}$. The oil was produced only before the water breakthrough, so that the displacement looked piston-like. Increasing the temperature to 70 and $120{ }^{\circ} \mathrm{C}$ produced no additional oil.

After completion of the first cycle, the core was resaturated with distilled water and, afterward, $7 \mathrm{pv}$ of crude oil was injected to establish the IWS. In the second cycle, the core was flooded with SWOS brine at 40, 70, and $120^{\circ} \mathrm{C}$, in the same way as for the first cycle. Also, in this case, no oil was produced after water breakthrough, and an increase in the temperature to 70 and $120^{\circ} \mathrm{C}$ did not result in additional production, as shown in Figure 2a. The total amount of oil produced was $54.4 \%$ OOIP. The effluent was analyzed for $\mathrm{Ca}^{2+}$ and $\mathrm{Mg}^{2+}$ ions at different temperatures. The results, plotted in Figure $2 b$, indicate that the concentration of $\mathrm{Ca}^{2+}$ and $\mathrm{Mg}^{2+}$ ions in the effluent increases with time at $40{ }^{\circ} \mathrm{C}$. This is because, at the initial stage of flooding, the distilled water, which was initially in the core, comes out of it. The concentration for both ions remains constant at $70{ }^{\circ} \mathrm{C}$, and the concentration of $\mathrm{Ca}^{2+}$ increases, while the $\mathrm{Mg}^{2+}$ concentration decreases in the effluent at $120{ }^{\circ} \mathrm{C}$.

In the third cycle, the core was resaturated with distilled water and then IWS was established in the same way as for the second cycle. In this case, the core was flooded with brine SW3S with the same injection rate of $2 \mathrm{pv} /$ day. This relatively slow injection rate was used to allow for the different potential determining ions to interact with the chalk matrix. The oil recovery at $40{ }^{\circ} \mathrm{C}$ was $56.1 \%$ OOIP, which is $1.7 \%$ higher than 


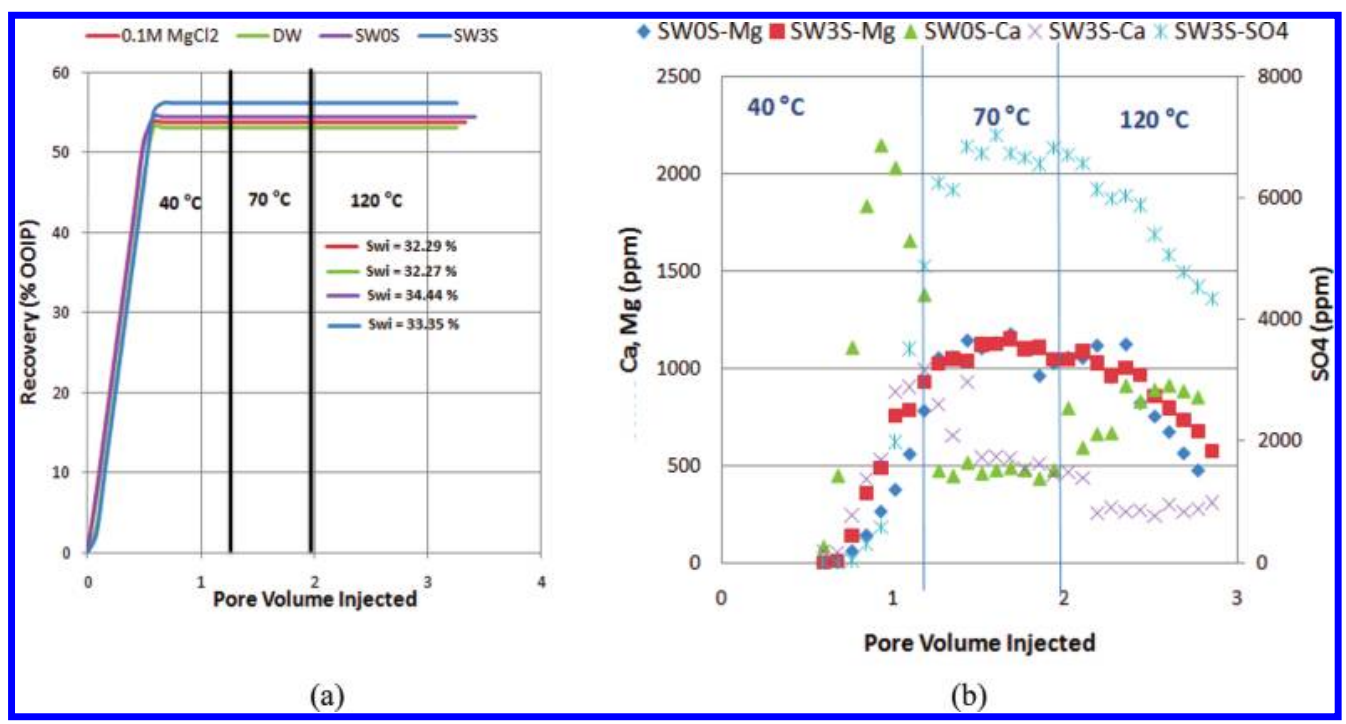

Figure 2. (a) Waterflooding in North Sea chalk core plug (1L) without aging, with oil recovery (\% OOIP) as a function of the pore volume injected. (b) Effluent ion concentrations as a function of the pore volume injected.

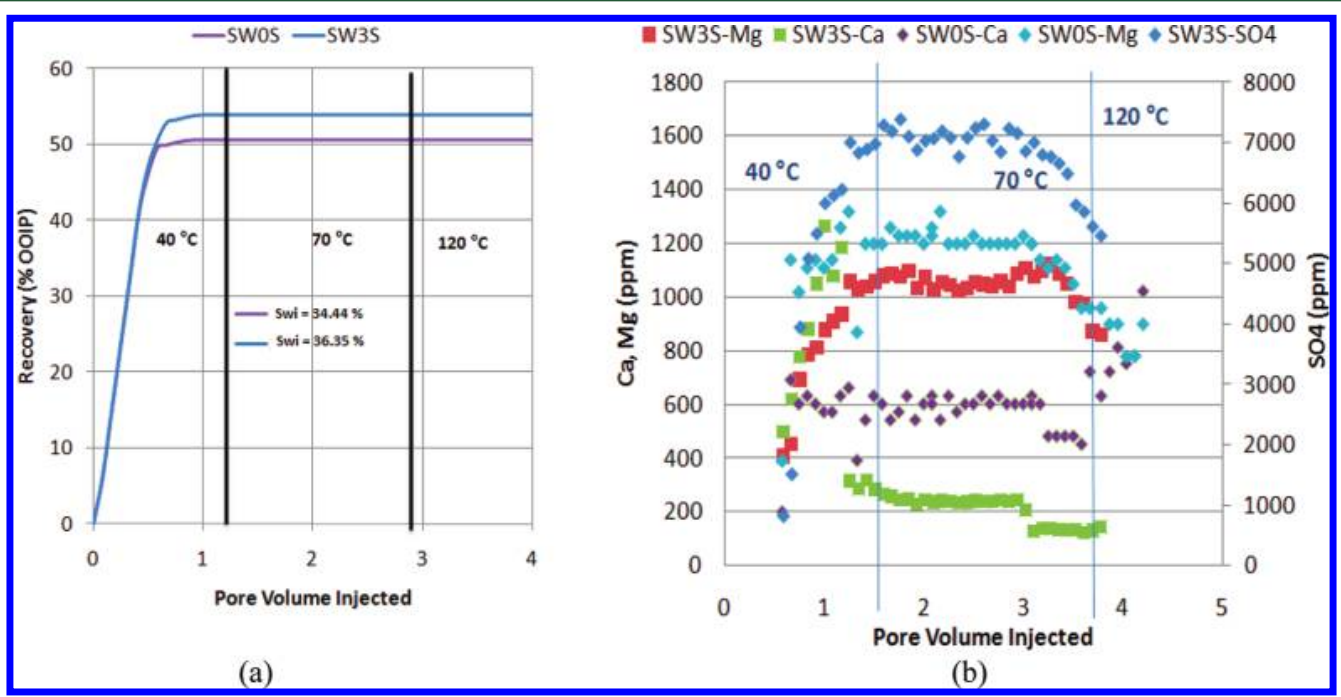

Figure 3. (a) Waterflooding in North Sea chalk (1L) core plug with aging, with oil recovery (\% OOIP) as a function of the pore volume injected. (b) Effluent ion concentrations as a function of the pore volume injected.

for the SWOS injection. Increasing the temperature to 70 and $120{ }^{\circ} \mathrm{C}$ did not improve the oil recovery. The concentration of the different potential determining ions increased with time at $40{ }^{\circ} \mathrm{C}$ and remained constant at $70{ }^{\circ} \mathrm{C}$, but at $120{ }^{\circ} \mathrm{C}$, the concentration of all of the ions decreased in the effluent.

In the fourth cycle, the core was flooded with the $0.1 \mathrm{M}$ $\mathrm{MgCl}_{2}$ brine solution in the same sequence as above, to check the effect of $\mathrm{Mg}^{2+}$ ions on the reservoir chalk core plug. A total of $53.8 \%$ OOIP of oil was produced in this case, which is less than for the SW3S flooding. Thus, in this case, $\mathrm{Mg}^{2+}$ ions did not help to give high oil recovery compared to $\mathrm{SO}_{4}{ }^{2-}$ ions. The effluent was also analyzed for $\mathrm{Ca}^{2+}$ and $\mathrm{Mg}^{2+}$ ions, and the trend in the $\mathrm{Mg}^{2+}$ ion concentration was the same as for the SW3S case.

3.1.2. Flooding Sequence 2. After completion of flooding sequence 1 , the core was resaturated with distilled water and IWS was established by flooding 3 pv of crude oil from both sides of the core plug. After IWS was established, the core was aged at $90{ }^{\circ} \mathrm{C}$ for 3 days. In the first cycle of this flooding sequence, the core was flooded with brine SWOS in the same way as in flooding sequence 1 . This resulted in a final oil recovery of 50.7\% OOIP. As shown in Figure 3a, most of the oil was produced before the water breakthrough but some oil was also produced after the breakthrough. For comparison, no oil was produced after breakthrough in flooding sequence 1 . Increasing the temperature to 70 and $120{ }^{\circ} \mathrm{C}$ did not improve the oil recovery. The effluent was also analyzed for $\mathrm{Ca}^{2+}$ and $\mathrm{Mg}^{2+}$ concentrations, which are plotted in Figure 3b. The reactivity trend of these ions with the rock is the same as in flooding sequence 1 . The concentration of $\mathrm{Ca}^{2+}$ in the effluent increases, while the concentration of $\mathrm{Mg}^{2+}$ decreases with time at $120{ }^{\circ} \mathrm{C}$. In cycle 2 of flooding sequence 2 , the core was flooded with brine SW3S, which resulted in an oil recovery of $53.4 \%$ OOIP. This is around $2.7 \%$ higher than for cycle 1 . No more oil was produced with the increase in the temperature even in this case. The effluent ion profile of $\mathrm{Ca}^{2+}, \mathrm{Mg}^{2+}$, and $\mathrm{SO}_{4}{ }^{2-}$ is plotted in Figure $3 \mathrm{~b}$.

In cycle 3 , we flooded the core plug (Swi $=35.1 \%$ ) with SWOS brine again to check for the repeatability of the tests. A 
total of $50.9 \%$ OOIP oil was produced, which is very much similar to the previous test (not plotted).

3.1.3. Formation Brine Composition. In all of the flooding tests and flooding sequences described until now, distilled water was used to establish IWS in the cores. One more test was carried out with the North Sea formation brine as initial water to check if this could affect the oil recovery mechanism. After the completion of flooding sequence 2, the core was cleaned with toluene and ethanol and was dried in an oven until constant weight was achieved. The core plug saturated with the North Sea formation brine and crude oil was flooded with the SW3S brine at different temperatures. As in the previous cases, in this case, an increase of the temperature did not result in a recovery increase, as shown in Figure 4. The effluent was

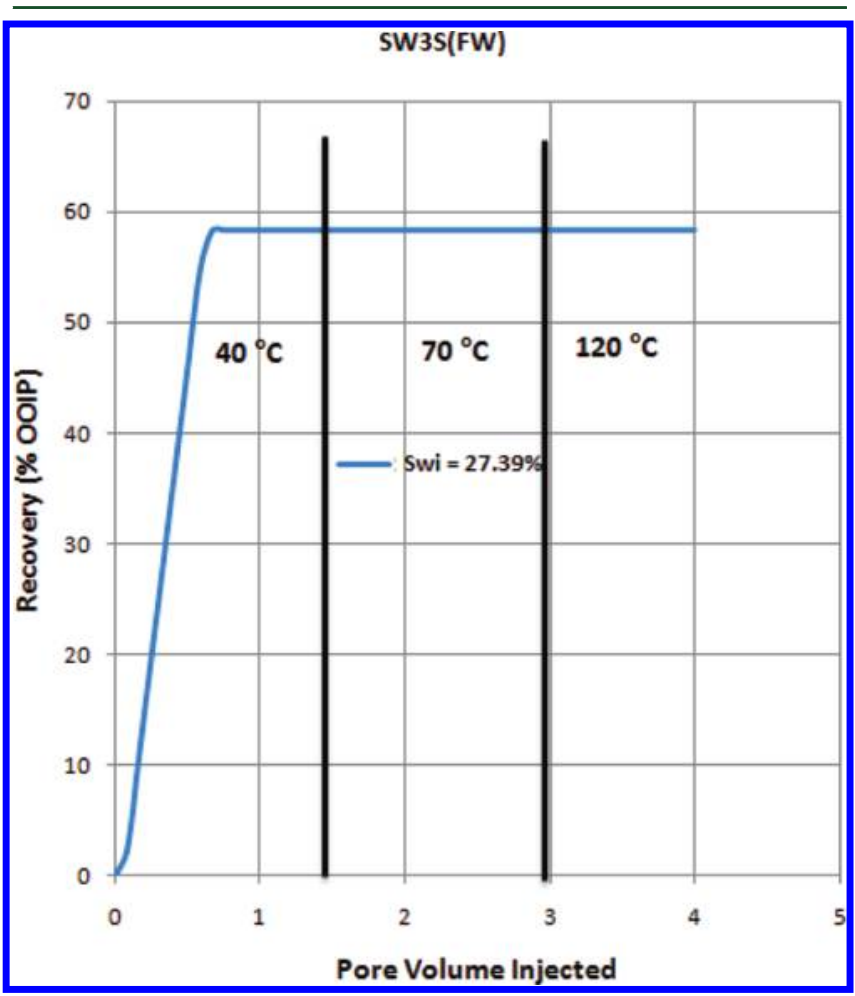

Figure 4. SW3S brine injection in North Sea chalk (1L) core plug without aging with North Sea formation brine as initial water.

analyzed for potential determining ions (not plotted). The reactivity trend of the ions remained the same as in the case of SW3S injection in flooding sequences 1 and 2.

3.2. North Sea Chalk Reservoir Core Plug (RE05). 3.2.1. Flooding Sequence 1. Another coreflood experiment was conducted using a different reservoir chalk core plug RE05 to see especially the effect of the temperature on oil recovery. The core was first flooded with brine SWOS in the same way as in flooding sequence 1 for the first North Sea chalk sample (1L) at different temperatures. As shown in Figure 5, 50.9\% OOIP was recovered after injection of SWOS at $40{ }^{\circ} \mathrm{C}$. A significant amount of oil was produced after water breakthrough. Increasing the temperature to 70 and $120^{\circ} \mathrm{C}$ resulted in an additional production of $2.2 \%$ OOIP.

In the second cycle, the core was flooded with the SW3S brine solution with the same injection rate and temperature sequence as was adopted for the first cycle. The oil recovery at $40{ }^{\circ} \mathrm{C}$ was $51.1 \%$ OOIP. Increasing the temperature to $70{ }^{\circ} \mathrm{C}$ and then to $120{ }^{\circ} \mathrm{C}$ resulted in an additional production of

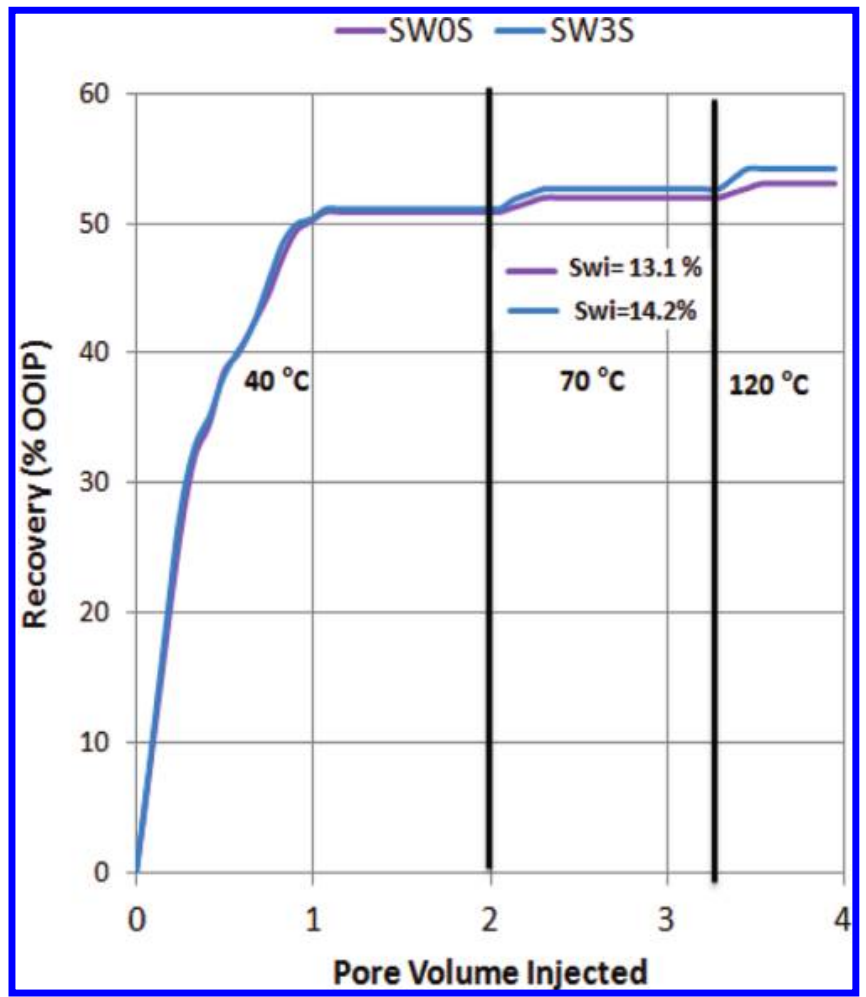

Figure 5. Waterflooding in North Sea chalk (RE05) core plug without aging, with oil recovery (\% OOIP) as a function of the pore volume injected.

$3.1 \%$ OOIP. For both cycles, oil production at $40{ }^{\circ} \mathrm{C}$ is approximately the same, as shown in Figure 5. However, at 70 and $120{ }^{\circ} \mathrm{C}$, the core plug flooded by SW3S brine produced approximately 0.7 and $1.2 \%$ OOIP more oil, respectively, compared to the core plug flooded with SWOS brine.

3.3. Stevns Klint Chalk Plugs. For comparison, two flooding tests were carried out with the Stevns Klint chalk cores. Both tests were carried out with the same injected fluid SW3S but with different compositions of water forming IWS. In the first test, the core was saturated with distilled water, after which IWS was established by flooding $7 \mathrm{pv}$ of crude oil. The saturated core plug was then flooded with SW3S at $40{ }^{\circ} \mathrm{C}$. This resulted in an oil recovery of $33.8 \%$ OOIP. As shown in Figure 6 , the oil production at water breakthrough was $26.1 \%$ OOIP, and after water breakthrough, an additional $7.7 \%$ OOIP was produced. Increasing the temperature to 70 and $120{ }^{\circ} \mathrm{C}$ resulted in an additional production of 0.4 and $3.7 \%$ OOIP, respectively. Thus, the temperature played an important role in recovering more oil after water breakthrough in the Stevns Klint case, which is in accordance with most of the previous studies. $^{5,22}$

In the second test, a core plug was saturated with the North Sea reservoir formation brine and then IWS was established by flooding with crude oil. Flooding was carried out with brine SW3S at $40{ }^{\circ} \mathrm{C}$ and resulted in an oil recovery of $34.6 \%$ OOIP. As shown in Figure 6, 8.9\% OOIP was produced after water breakthrough. Increasing the temperature to $70{ }^{\circ} \mathrm{C}$ and then to $120{ }^{\circ} \mathrm{C}$ resulted in an additional production of 2.3 and $6.6 \%$ OOIP, respectively.

The effluent was analyzed for the three potential determining ions for both tests, and the concentration profiles are presented in Figure 7. In Figure $7 \mathrm{a}$, at $40{ }^{\circ} \mathrm{C}$, the concentration of all of the ions increases with time (because initial formation water is 


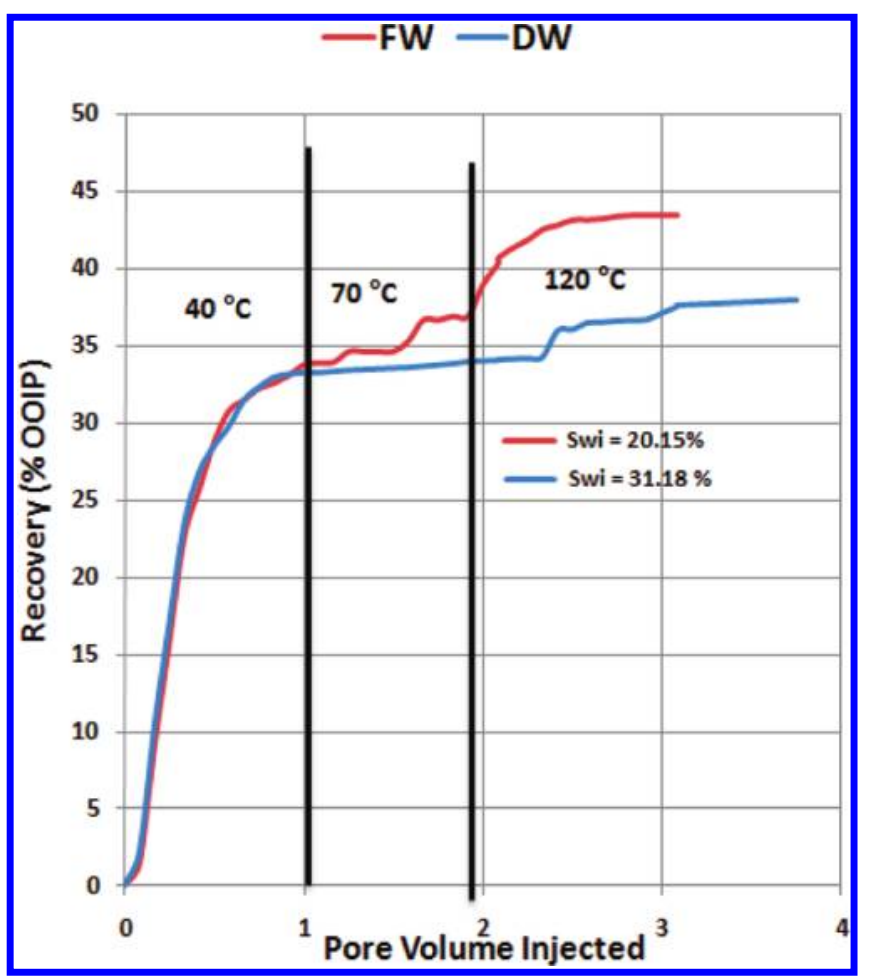

Figure 6. SW3S brine injection in two Stevns Klint chalk core plugs without aging with distilled water and North Sea formation brine as initial water.

distilled), remains constant at $70{ }^{\circ} \mathrm{C}$, and decreases at $120^{\circ} \mathrm{C}$. In Figure $7 \mathrm{~b}$, the calcium ion concentration decreases at $40{ }^{\circ} \mathrm{C}$ because the formation water already has a high calcium concentration compared to the injected brine SW3S. The reactivity trend of the rest of the ions at different temperatures is the same as for the first test.

\section{DISCUSSION}

\subsection{Effect of Reactivity of Potential Determining lons.} It has been established that seawater is an excellent injection fluid for high-temperature chalk reservoirs because of the presence of potential determining ions $\mathrm{SO}_{4}{ }^{2-}, \mathrm{Ca}^{2+}$, and $\mathrm{Mg}^{2+}$. ${ }^{22}$ We have carried out all of the experiments at both low and high temperatures to investigate the potential of seawater flooding. We observed no increment in oil recovery with an increase in the temperature for both flooding sequences (with and without aging) for reservoir chalk sample $1 \mathrm{~L}$. On the contrary, experiments with the Stevns Klint outcrop chalk showed a very clear effect of the temperature. Increasing the temperature produced additional 4.1 and 5.2\% OOIP oil for the first and second tests, respectively (see Figure 6). For another reservoir rock sample RE05, increasing the temperature resulted in an additional oil recovery of 2.2 and $3.1 \%$ OOIP during SWOS and SW3S brine flooding, respectively.

Strand et al. ${ }^{9}$ mentioned reactivity of potential determining ions (rock-fluid interactions and symbiotic interactions between the three ions: $\mathrm{Ca}^{2+}, \mathrm{Mg}^{2+}$, and $\mathrm{SO}_{4}{ }^{2-}$ or mutual affinity of the ions toward the rock) with the chalk surface as a necessary condition for improving the oil recovery. This reactivity increases with an increase in the temperature for reservoir (1L) and outcrop rock. Meanwhile, recovery in our experiments increased with the temperature only for reservoir rock RE05 and the outcrop chalk samples. The effect for the reservoir rock RE05 was considerably lower than for the outcrop chalk. No effect of the temperature on oil recovery was observed in the case of reservoir rock $1 \mathrm{~L}$.

One explanation of the observed difference might be that potential determining ions did not react in the same way with the reservoir chalk $(1 \mathrm{~L})$ as with the Stevns Klint rock. However, Figures $2 b, 3 b, 7 a$, and $7 b$ show that the reactivity trend of potential determining ions at different temperatures is the same for both rocks (1L and Stevns Klint). Thus, it is possible that, in some rock, the potential determining ions react with the internal porous surface, but this has no effect on the recovery. For such reservoir rocks, it is not the ion interaction that controls the oil recovery process. However, for other reservoir rocks, such as RE05, it could be the controlling mechanism of the oil recovery process.

In general, the concentration of all potential determining ions at high temperature decreases in the effluent. This decrease in

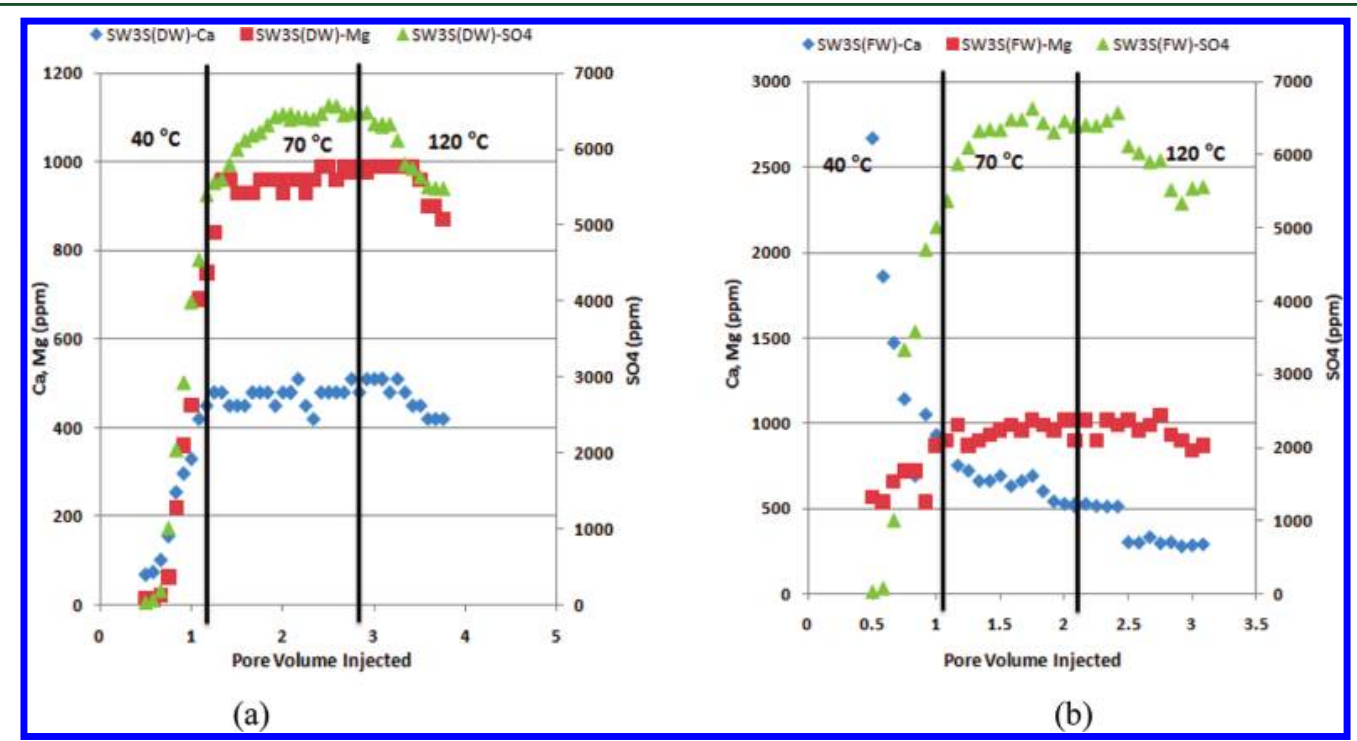

Figure 7. (a) Effluent ion concentrations during SW3S brine injection in Stevns Klint chalk core plugs with distilled water as initial water. (b) Effluent ion concentrations during SW3S brine injection in Stevns Klint chalk core plugs with North Sea formation brine as initial water. 


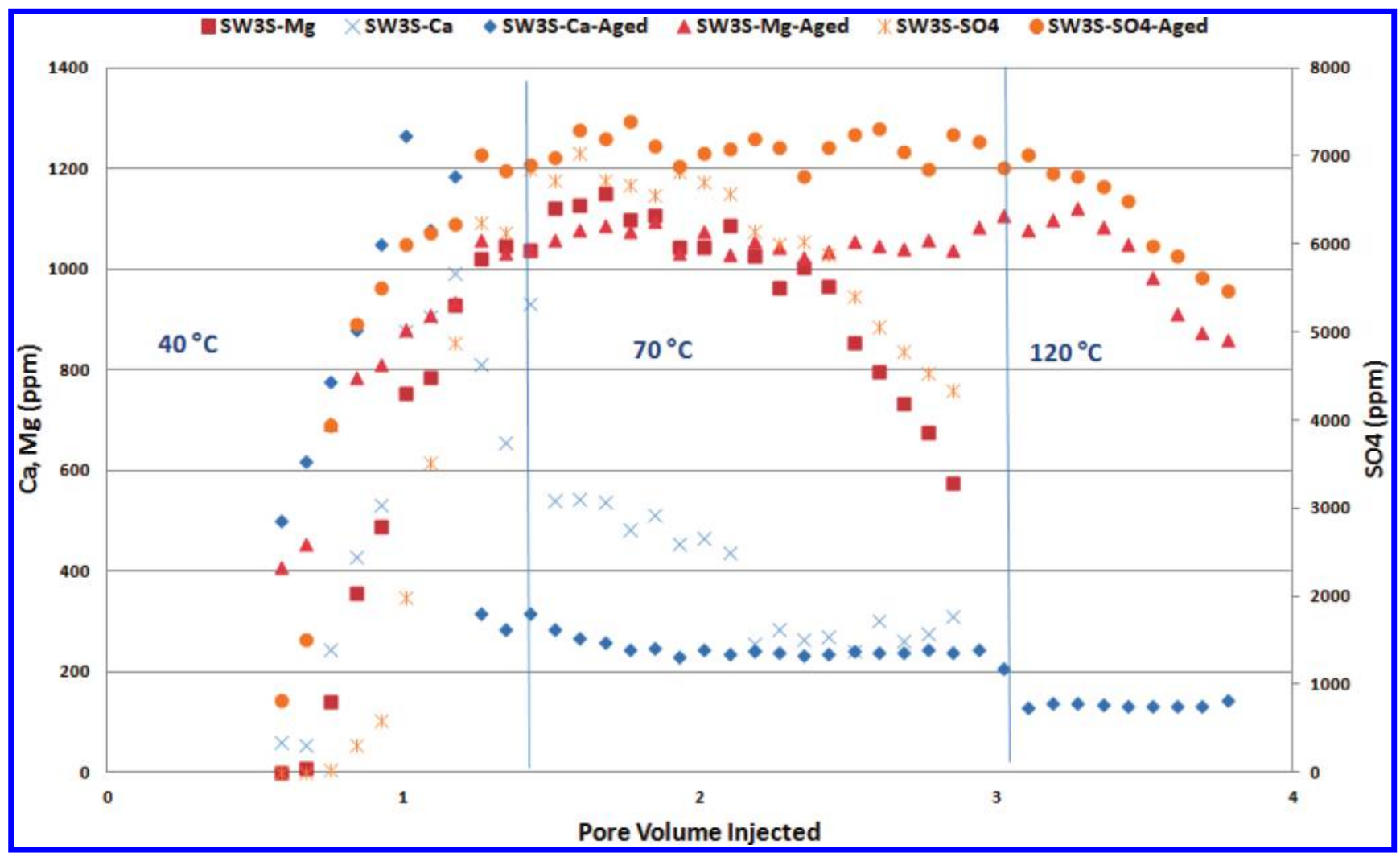

Figure 8. Effluent ion concentrations during SW3S brine injection at different wetting conditions in North Sea chalk core plug (1L). Comparatively, a lesser loss of ions is observed in the case of aging.

the concentration could be because of high adsorption (Austad et al. ${ }^{7}$ reported high adsorption of sulfate at high temperatures) or in situ precipitation of $\mathrm{CaSO}_{4}$.

The lack of extra recovery at high temperatures in reservoir rock (1L) is not because of the low acid number of crude oil (see Table 2) because the same crude oil was used for all rock types (North Sea chalk samples and Stevns Klint). We think the reason belongs to the rock, but right now, it is difficult to explain the exact mechanism; therefore, we just reported this interesting observation.

Thus, according to the above analysis, the different temperature effect on the different rock samples cannot be explained by the reasons commonly discussed in the literature and needs further study.

4.2. Reactivity of Potential Determining lons and Effect of Aging. Verification of the aging effect on recovery is achieved by a comparison of the flooding experiments with and without aging (see section 3.1.2). The concentrations of the effluent ions are plotted in Figure 8 for both flooding schemes. As shown in the figure, for injection of the SW3S brine, the ion interaction behavior is similar with and without aging but a lesser loss of ions is observed in the case of aging. This could be because the oil layer formed on the rock surface by aging hinders or prevents reaction. The results are similar for injection of SWOS (not plotted).

4.3. Substitution Reaction. Zhang et al. ${ }^{10}$ reported an increase in the effluent calcium concentration during seawater flooding in Stevns Klint at temperatures above $100{ }^{\circ} \mathrm{C}$. This effect was interpreted as a result of substitution of $\mathrm{Ca}^{2+}$ by $\mathrm{Mg}^{2+}$ ions on the internal rock surface. This substitution reaction is reported as a possible reason for an increment in oil recovery.
In our experiments, we did not observe this substitution reaction during SW3S flooding, with either Stevns Klint rock or the reservoir chalk (1L). Unexpectedly, an increase in the $\mathrm{Ca}^{2+}$ ion concentration was observed above $100{ }^{\circ} \mathrm{C}$ during SWOS flooding in reservoir chalk (1L) for both flooding sequences, but the mechanism of this is not clear.

4.4. Effect of the Composition of Formation Brine. The effect of the composition of the formation brine was studied and tested in the two experiments with the Stevns Klint core plugs. The IWS was formed by the distilled water for the first plug (Swi $=31.18 \%)$ and the reservoir brine for the second plug (Swi $=20.15 \%)$, as described in section 3.2. This significant difference in IWS shows that initial water composition also affect the displacement with crude oil. This was also observed in the case of reservoir core $1 \mathrm{~L}$ (5\% difference). For both tests with Stevns Klint plugs, the oil production at $40{ }^{\circ} \mathrm{C}$ is approximately the same, as shown in Figure 6. However, at 70 and $120{ }^{\circ} \mathrm{C}$, the core plug initially saturated by formation brine produced approximately 2 and $3.2 \%$ OOIP more oil, respectively, compared to the core plug saturated with distilled water. This indicates that not only the injection brine composition but also different ions in the formation brine can increase the oil recovery at high temperatures. This difference in oil recovery may not be attributed to the difference in IWS, because if this was the reason, then there should be a difference in oil recovery at 40 ${ }^{\circ} \mathrm{C}$ also. At high temperatures, some ions in the formation water take part in improving the recovery, but how the different ions in formation brine affect the oil recovery is not yet clear. In the reservoir chalk $(1 \mathrm{~L})$ case, high temperatures did not help to improve the oil recovery for the different compositions of the formation brine. 
4.5. Outcrop Chalk as a Substitute in Flooding Tests.

The outcrop rock was used in many studies as a model for reservoir rock because of easy availability and good rock characterization. We used both the reservoir and outcrop rocks for this study. Experimental results demonstrate that the oil recovery mechanism at high temperatures is different for the different rocks, although they have similar surface area and reactivity of potential determining ions. Enrichment of the brine by sulfate ions increased oil recovery under water-wetting conditions, but the comparatively less recovery increment was observed for the reservoir core plugs than for the Stevns Klint outcrop chalk. Recovery in the experiments with the outcrop chalk is strongly temperature-dependent. ${ }^{9}$ Meanwhile, the experiments with the reservoir chalk rocks showed relatively less effect of the temperature compared to Stevns Klint in one case (RE05) and no effect of the temperature in another case (1L). This indicates that the rock may also determine whether the effect of the temperature on the recovery is observed. We also acknowledged that the much lower recovery at $40{ }^{\circ} \mathrm{C}$ for the outcrop (less than $35 \%$ OOIP) could contribute to its increased scope for further recovery at the higher temperatures compared to the reservoir core plugs (which had already established quite high recovery $>50 \%$ at $40{ }^{\circ} \mathrm{C}$ ). From many years, reservoir rock stayed with crude oil, temperature, and pressure, and this is not the case with outcrop rock. This could be the reason for the different responses of reservoir rock, especially with regard to temperature, compared to outcrop. Thus, care should be taken in using outcrop chalk as a model of reservoir chalk and, in particular, for the water-based improved oil recovery (IOR).

\section{CONCLUSION}

(1) The temperature did not affect oil recovery in experiments with one reservoir rock sample and showed relatively less effect for another reservoir rock sample, while flooding of the Stevns Klint outcrop chalk rock was strongly affected by the temperature. (2) The interaction of different ions with rock depends upon the temperature; meanwhile, for the recovery, this is not always the case. This indicates that, in some rocks, the interaction of the ions with rock is not the main controlling factor for the oil recovery process. However, for other reservoir rocks, it could be the controlling parameter. (3) In two different flooding schemes (with and without aging of the core plug), the trend of the interaction of ions with reservoir rock remains the same but a comparatively smaller loss of ions was observed in the aged core. (4) Enrichment of the brine by sulfate ions increased oil recovery under water-wetting conditions, but the comparative recovery increment was less for the reservoir core plugs than for the Stevns Klint outcrop chalk. (5) No substitution of $\mathrm{Ca}^{2+}$ ions by $\mathrm{Mg}^{2+}$ ions was observed at high temperature for the Stevns Klint cores. (6) The initial brine composition showed an effect on oil recovery at high temperature for the outcrop chalk but not for the reservoir rock. (7) Care should be taken in using outcrop chalk as a model of reservoir chalk and, in particular, for the waterbased IOR. Salinity-based enhanced oil recovery (EOR) needs to be checked in each particular case of rock.

\section{AUTHOR INFORMATION}

\section{Corresponding Author}

*Telephone: +45-45252881. Fax: +45-45882258. E-mail: ash@ kt.dtu.dk.

\section{Notes}

The authors declare no competing financial interest.

\section{ACKNOWLEDGMENTS}

We are grateful to DONG Energy and the Danish Council for Independent Research Technology and Production Sciences (FTP) for funding this study as a part of the ADORE Project. The authors also thank Helle F. Christensen at GEO Denmark for providing the Stevns Klint core plugs used in this study.

\section{REFERENCES}

(1) Zhang, Y.; Morrow, N. R. Comparison of secondary and tertiary recovery with change in injection brine composition for crude-oil/ sandstone combinations. Proceedings of the Society of Petroleum Engineers (SPE)/Department of Energy (DOE) Symposium on Improved Oil Recovery; Tulsa, OK, April 22-26, 2006.

(2) Zhang, Y.; Xie, X.; Morrow, N. R. Waterflood performance by injection of brine with different salinity for reservoir cores. Proceedings of the Society of Petroleum Engineers (SPE) Annual Technical Conference and Exhibition; Anaheim, CA, Nov 11-14, 2007.

(3) Lager, A.; Webb, K. J.; Collins, I. R.; Richmond, D. M. LoSal enhanced oil recovery: Evidence of enhanced oil recovery at the reservoir scale. Proceedings of the Society of Petroleum Engineers (SPE)/ Department of Energy (DOE) Symposium on Improved Oil Recovery; Tulsa, OK, April 19-23, 2008.

(4) Strand, S.; Høgnesen, E. J.; Austad, T. Wettability alteration of carbonates-Effects of potential determining ions $\left(\mathrm{Ca}^{2+}\right.$ and $\left.\mathrm{SO}_{4}{ }^{2-}\right)$ and temperature. Colloids Surf. A 2006, 275 (1-3), 1-10.

(5) Zhang, P.; Tweheyo, M. T.; Austad, T. Wettability alteration and improved oil recovery by spontaneous imbibition of seawater into chalk: Impact of the potential determining ions $\mathrm{Ca}^{2+}, \mathrm{Mg}^{2+}$, and $\mathrm{SO}_{4}{ }^{2-}$. Colloids Surf. A 2007, 301 (1-3), 199-208.

(6) Hermansen, H.; Landa, G. H.; Sylte, J. E.; Thomas, L. K. Experiences after 10 years of waterflooding the Ekofisk Field, Norway. L. Pet. Sci. Eng. 2000, 26 (1-4), 11-18.

(7) Austad, T.; Strand, S.; Høgnesen, E. J.; Zhang, P. Seawater as IOR fluid in fractured chalk. Proceedings of the Society of Petroleum Engineers (SPE) International Symposium on Oilfield Chemistry; The Woodlands, TX, Feb 2-4, 2005.

(8) Puntervold, T.; Strand, S.; Austad, T. Coinjection of seawater and produced water to improve oil recovery from fractured North Sea chalk oil reservoirs. Energy Fuels 2009, 23 (5), 2527-2536.

(9) Strand, S.; Puntervold, T.; Austad, T. Effect of temperature on enhanced oil recovery from mixed-wet chalk cores by spontaneous imbibition and forced displacement using seawater. Energy Fuels 2008, 22 (5), 3222-3225.

(10) Zhang, P.; Austad, T. Wettability and oil recovery from carbonates: Effects of temperature and potential determining ions. Colloids Surf., A 2006, 279 (1-3), 179-187.

(11) Webb, K. J.; Black, C. J. J.; Tjetland, G. A laboratory study investigating methods for improving oil recovery in carbonates. Proceedings of the International Petroleum Technology Conference; Doha, Qatar, Nov 21-23, 2005.

(12) Fjelde, I. F.; Aasen, S. M. A. Improved spontaneous imbibition of water in reservoir chalks. Proceedings of the 15th European Symposium on Improved Oil Recovery; Paris, France, April 27-29, 2009.

(13) Karoussi, O.; Hamouda, A. A. Imbibition of sulfate and magnesium ions into carbonate rocks at elevated temperatures and their influence on wettability alteration and oil recovery. Energy Fuels 2007, 21 (4), 2138-2146.

(14) Madland, M. V.; Hiorth, A.; Korsnes, R. I.; Evje, S.; Cathles, L. Rock fluid interactions in chalk exposed to injection of seawater, $\mathrm{MgCl}_{2}$, and $\mathrm{NaCl}_{2}$ brines with equal ionic strength. Proceedings of the 15th European Symposium on Improved Oil Recovery; Paris, France, April 27-29, 2009; A22.

(15) Bagci, S.; Kok, M. V.; Turksoy, U. Effect of brine composition on oil recovery by waterflooding. Pet. Sci. Technol. 2001, 19 (3), 359372. 
(16) Skauge, A.; Sørvik, A.; Vik, B.; Spildo, K. Effect of wettability on oil recovery from carbonate material representing different pore classes. Proceedings of the International Symposium of the Society of Core Analysts; Trondheim, Norway, Sept 12-16, 2006.

(17) Hiemenz, P. C.; Rajagopalan, R. Principles of Colloid and Surface Chemistry; CRC Press (Taylor and Francis Group): Boca Raton, FL, 1997.

(18) Puntervold, T.; Strand, S.; Austad, T. Water flooding of carbonate reservoirs: Effects of a model base and natural crude oil bases on chalk wettability. Energy Fuels 2007, 21 (3), 1606-1616.

(19) Zahid, A.; Stenby, E. H.; Shapiro, A. A. Improved oil recovery in chalk: Wettability alteration or something else? Proceedings of the Society of Petroleum Engineers (SPE) EUROPEC/European Association of Geoscientists and Engineers (EAGE) Annual Conference and Exhibition; Barcelona, Spain, June 14-17, 2010.

(20) Fan, T.; Buckley, J. S. Acid number measurements revisited. $\underline{S P E}$ I. 2007, 12 (4), 496-500.

(21) Tang, G. Q.; Firoozabadi, A. Effect of pressure gradient and initial water saturation on water injection in water-wet and mixed-wet fractured porous media. SPE Reservoir Eval. Eng. 2001, 4 (6), 516-524.

(22) Puntervold, T.; Strand, S.; Austad, T. New method to prepare outcrop chalk cores for wettability and oil recovery studies at low initial water saturation. Energy Fuels 2007, 21 (6), 3425-3430. 